\title{
Entrepreneurial Orientation and International Fundraising by Civil Society Organizations
}

\author{
Mariana Cristina Betti Cury Lorca ${ }^{1}$ \\ mariana.c.lorca@gmail.com | (100000-0002-8554-4861 \\ Ilan Avrichir ${ }^{1}$ \\ iavrichir@espm.br | @0000-0001-8234-3872
}

\begin{abstract}
This article examines how certain Civil Society Organizations (CSOs) from Emerging Economies (EE) are able to raise funds from International Development Agencies (IDAs) while others are not successful in this endeavor. Following a multiple case study involving six Brazilian CSOs, our results suggest that one of the factors that explain the success of CSOs in international fundraising is Entrepreneurial Orientation (EO), which allows some of them to develop innovative approaches aligned with the guidelines of international development agencies. These results contribute to the expansion of the theoretical domain in which the EO construct is important for international fundraising, a field that has been explored little in the literature. From a practical viewpoint, the study suggests that CSOs that wish to raise funds from IDAs should promote EO internally.
\end{abstract}

\section{KEYWORDS}

entrepreneurial orientation, international fundraising, civil society organizations, international strategy 


\section{INTRODUCTION}

CSOs are important development agents. They are part of the Third Sector, representing organized civil society, and providing humanitarian, socio-economic, and environmental aid, as well as defending rights (Salamon, Sokolowski, Megan, \& Tice, 2013). They are formal, private, and non-profit organizations. They are not part of the government (First Sector) or the market (Second Sector). They are managed autonomously and mobilize voluntary work (Lewis, 2014; Salomon \& Anheier, 1997).

The ability of CSOs to develop, accomplish their missions, and achieve their goals depends on how efficient they are at raising sufficient funds . Therefore, fundraising is an essential activity for CSOs (Aldashev \& Verdier, 2010). The economic dimension is crucial to the sustainability of these organizations and fundraising is often the greatest problem they face (Stankiewicz \& Seiler, 2013). Although many of the resources that sustain CSOs come from within the countries in which they operate, many of them depend on funding from IDAs (Anheier, 2014; Lewis, 2014; Appe \& Pallas, 2018).

The globalization of the donation market is a recent phenomenon (Aldashey \& Verdier, 2010) and this may be why Buijze (2017) asserts that the literature on International Fundraising (IF) remains limited, and that philanthropy between countries is a topic that requires further research. Due to the limited literature, confirmed by our bibliographic research, much of what has been published is in the form of guidelines and prescriptions regarding how to raise funds, little of which is based on systematic evidence (Pereira, 2001; Ferrari, 2014; Gallagher \& Meyers, 2016).

Many of the studies based on research emphasize that changes have recently been made in the policies and practices of international donors, which have made fundraising more difficult and problematic for CSOs (Lewis, 2014; Missoni \& Alesani, 2014; Wallace, 2004). However, this literature has provided few indications regarding strategic postures or other alternatives regarding how CSOs can address these issues.

In this qualtiative, comparative, case study (Yin, 2014), using the Eisenhardt template (Langley \& Abdallah, 2011) to compare cases, we used the EO construct as a theoretical reference for analyzing six CSOs with volumes of international fundraising and part of their budgets covered by this form of fundraising that differ greatly from one another. EO has to do with a company's strategy creation processes, managerial philosophies, and behavior, at the company level, that could be described as innovative, proactive, and risky (Covin \& Slevin, 1989; Miller, 1983). The use of $\mathrm{EO}$ as a reference framework for this study is justified because strong $\mathrm{EO}$ is increasingly considered important to companies that seek new opportunities (Wales, Gupta, \& Mousa, 2011; Rank \& Strenge, 2018).

Many previous studies made a direct connection between EO and improved company performance, including Rauch, Wiklund, Lumpkin and Frese (2009) and Wiklund and Shepherd (2011). However, less academic attention has been paid to examining processes that permit entrepreneurial companies to enjoy good performance (Ranke \& Strenge, 2018). We propose an analysis of this nature in the present study. According to Wales, Wiklund and McKelvie (2013) and Cui, Fan, Guo, \& Fan (2018), the underlying generative mechanisms regarding EO and performance have yet to be sufficiently identified in research.

Therefore, two objectives serve as the driving force of this study. One is of a practical nature: analyzing cases in order to identify orientations, or at least questions that might contribute to the management of CSOs that intend to seek international funding from IDAs. The other objective 
is of a theoretical nature: to examine the process that allows a CSO to raise international funds. The theoretical objective and contribution of the article also includes demonstrating how EO influences the performance of an organization in the context of IF, a sector in which this construct has been little analyzed.

The theoretical objective is justified because, following its emergence, research on entrepreneurship has spread to diverse fields, such as the international, political, and institutional context, using EO as a tool to support it. However, these studies failed to capture particular aspects of entrepreneurship. This failure is more significant with regard to non-profit organizations, in that they represent a very unique context compared with business organizations (Morris, Webb, \& Franklin, 2011). As different organizational forms can lead to different directors of EO (Miller, 1983), limited samples with specific types of organizations, or industrial contexts, are necessary to gain a better understanding of differences in EO in different contexts. Studies have called for the concept of EO to be addressed in specific contexts, with Morris et al. (2011) specifically mentioning nonprofits as a promising field for this purpose.

Regarding the adoption of a qualitative design, despite the numerous and repeated appeals through the years, there have been almost no studies of this type on EO (Wales, 2016). Miller (2011), Wiklund and Shepherd (2011) and Covin and Miller (2014) are some of the scholars who have appealed for the continuity of research in this field. Lumpkin and Dess (1996) suggested that qualitative studies could offer insights into how the dimensions of EO are manifested and can be captured empirically. Miller (2011) noted that diverse qualitative tools could be useful for understanding the "how and why" of EO. Wales (2016) ended a section of his article "The Enduring and Unanswered Call for Qualitative Research" by voicing the expectation that qualitative research provides greater insight into how EO plays out in organizations, resulting in greater congruence between theory and practice.

\section{LITERATURE REVIEW}

\subsection{INTERNATIONAL FUNDRAISING}

One aspect that became clear in the search for a theoretical framework on the theme in the literature regarding international fundraising was how limited this literature was. A search for the term "International Fundraising" in titles, key words and abstracts in the Scopus database resulted in five references. A search for the same term in the Web of Science base had even fewer results. A search on Google Scholar mostly added guidelines and prescriptions written by consultants, very few of which were based on systematic evidence. This may be due to the fact that, although CSOs, also known as Non-Governmental Organizations (NGOs), have existed at least since the end of World War II, it was only in the nineteen nineties that they "catapulted into international respectability" (Lewis, 2014, p. 81) and came to be viewed by governments and multilateral institutions as important players in development.

Gautier and Pache (2013), for example, reviewed and analyzed 162 academic articles on the theme of corporate philanthropy. They found that these articles could be categorized into four lines of research, none of which was related to IF. Uncapher (2013) analyzed the relationship between EO and the organizational effectiveness of CSOs, but did not include the theme as a research object. The meta-analysis by Rauch, Wiklund, Lumpkin and Frese (2009) on the relationship between $\mathrm{EO}$ and performance was limited to companies. 
BBR

17

172

Another aspect that attracts attention is the strong concentration of studies on the fact that fundraising is becoming increasingly difficult. Wallace (2004), in analyzing the transformations in the environment in which CSOs operate, found that it has become acceptable for donors to make demands related to social policies, budget allocations, and financial report systems. Donors increasingly demand concrete evidence from CSOs regarding changes, even when measuring the impact of CSOs' actions is extremely difficult. CSOs have increasingly been required to compete for contracts designed to satisfy the agendas of IDAs. In this context, the CSO teams have had to dedicate a growing number of hours to preparing detailed reports written in English.

Missoni and Alesani (2014) claimed that, although the interest of western donors in CSOs has increased since the nineteen seventies, fundraising from international sources is not an easy task for them. This is because the requirements and controls imposed by donors have become much stricter. Donors have come to look favorably on quick results that inhibit the learning and reflection of CSOs. Another difficulty that CSOs face is what has come to be known as project tyranny. The project allows donors to control an intervention using a logical planning model. On the other hand, it makes it difficult for communities to manage their own programs. Although some CSOs have professionalized their management, the speed and frequency of change have made their relationship with the international donation system more difficult.

Ferrari (2014) identified similar points, claiming that subsidies and funding require CSO's planning to involve increasingly more budgetary and accounting documents and detailed reports. Fundraising events need more and more publicity, promotion, relationships with the media and supporters. Third Sector organizations are increasingly required to produce evidence that they adopt quality improvement processes, detailed financial statements, audits, and controlled sustainability plans.

Some authors have researched characteristics of CSOs that facilitate fundraising. Zappala and Lyons (2006) found that young organizations experience more difficulty in fundraising than older ones because they have not had sufficient time to win the trust of donors. Size is another influential factor. Larger organizations may raise less funds because they are more likely to already have a diverse base of sources of revenue and depend less on fundraising. Organizations in large cities tend to find fundraising easier. CSOs that serve their own members, such as sport clubs and professional association can count on fees paid by members and thus depend less on fundraising. However, we found far fewer studies in this line of research than those pointing out that changes in the level and type of demands made by IDAs have made it more difficult for CSOs to raise funds at the international level.

Among the difficulties identified in the search of the literature on international fundraising is that fact that private donors tend to be more familiar with local CSOs and problems of information asymmetry tend to increase when donating to international CSOs (Herzer \& Nunnenkamp, 2013). Donor NGOs are mostly from the northern hemisphere and are rooted in their own societies. They increasingly recruit advisors and executives from the business sector and import tools and focuses from this sector. These tools and sectors are based on the paradigm of new public management, which focuses on a logic of process, control, measurement, and accountability (Wallace, 2004). These tools carry many cultural understandings. They are always in English and tend to be written in the highly t bureaucratic language of donor NGOs. 


\subsection{Entrepreneurial Orientation}

EO refers to the strategic orientation of organizations and encompasses aspects of their decisionmaking styles, methods, and practices (Covin \& Lumpkin, 2011; Zucchella \& Magnani, 2016). Since the seminal article by Miller (1983), EO has been viewed as one of the most important concepts in the field of entrepreneurship (Wales, Monsen, \& McKelvie, 2011). The concept of EO was originated to explain, in practical and behavioral terms, the meaning of what it is for a company to be entrepreneurial (Covin \& Miller, 2014). From the outset, research on EO has never ceased to expand (Covin \& Wales, 2018) and the number of articles on the theme has already surpassed those that examine the topic of cooperative entrepreneurship (Wales, 2016).

The adoption of strong EO is considered increasingly important for firms seeking new opportunities (Rank \& Strenge, 2018). The importance of EO to the internationalization of companies has been demonstrated in the field of Born Globals (Weerawardena, Mort, Liesch, \& Knight, 2007; Knight \& Liesch, 2016). Research on international performance has shown a significant positive relationship between $\mathrm{EO}$ and international performance indicators (Covin \& Miller, 2014). Liu, Li and Xue (2011), for instance, found a strong positive association between EO and the search for international markets. Zhang, Ma and Wang (2012) indicated that the dimensions of $\mathrm{EO}$ are positively associated with the percentage of sales made overseas and the number of countries to which companies export. The positive relationship between EO and internationalization is also supported by Dai, Maksimov, Gilbert and Fernhaber (2014), Fernández-Mesa and Alegre (2015) and Wales (2016).

Expanding research on EO led scholars to promote its applicability to numerous variants, such as international entrepreneurship, political entrepreneurship, academic entrepreneurship, and social entrepreneurship, suggesting subtle but important differences in entrepreneurial forms in these different contexts (Morris, Webb, \& Franklin, 2011). Miller (2011) postulated that entrepreneurship manifested in various ways according to different organizational contexts (size of company, manager's profile, structural aspects). The importance of expanding studies on EO to particular contexts, especially applying them to non-profit organizations, was pointed out by George and Marino (2011) and Morris et al. (2011) and reaffirmed by Wales (2016).

Non-profit organizations represent a particular context, characterized by significant differences compared with the traditional form of entrepreneurship of for-profit organizations. Non-profit organizations are self-governed entities, formed to address a social need, and do not seek to make a profit (Boris \& Steurle, 2006; Morris, Webb, \& Franklin, 2011). Non-profit organizations are not motivated by the creation of wealth for their owners, but rather by the need to serve a social purpose (Austin, Stevenson \& Wei-Skillern, 2006; Moss et al., 2011). Gamble and Moroz (2014) proposed the hypothesis that the relationship between EO and performance might differ greatly between for-profit and non-profit organizations. Slevin and Terjesen (2011) noted that there is a great opportunity for integration in the EO literature by understanding how it improves performance in particular contexts and settings.

Although EO is considered a core construct of entrepreneurship (Zucchella \& Magnani, 2016), strategy (Covin \& Slevin, 1989) and internationalization (Dai et al., 2014), it is not always defined consistently in the literature (Covin \& Miller, 2014). Covin and Slevin (1989) argued that $\mathrm{EO}$ is a composite construct that conjugates the qualities of proactiveness, innovativeness and risk taking by what they have in common. In another proposal, according to Lumpkin and Dess (1996), EO is a multidimensional construct in which proactiveness, innovativeness, risk 
BBR

17

174

taking, competitiveness, and autonomy are independent dimensions that define the conceptual space of EO.

Despite the inconsistencies regarding the definition of EO, most authors agree that it is a combination of three main dimensions (proactiveness, innovativeness, and risk taking), and these dimensions are related to the superior performance of an organization. Some researchers see the proliferation of different constructs in a very negative light and claim that a return to the concept of Covin and Slevin (1989) would encourage the creation of cumulative knowledge (Morris et al., 2011).

Lumpkin and Dess (1996) refer to innovativeness as being a "tendency to engage in and support new ideas, novelty, experimentation, and creative processes that may result in new products, services, or technological processes" (Lumpkin \& Dess, 1996, p. 142). To assess whether organizations are innovative, it is assumed that this dimension of EO (innovativeness) has fundamental characteristics such as the tendency to: (1) experiment and promote new ideas; (2) move away from established practices; and (3) introduce new lines of products, services and processes (Covin \& Slevin, 1989; Dai et al., 2014; Tayanuova, 2011).

Proactiveness is formulated as being "aimed at anticipating and acting on future needs by seeking opportunities that may or may not be related to the present line of operations, introduction of new products, and brands ahead of competition, strategically eliminating operations which are in the mature or declining stages of life cycle" (Lumpkin \& Dess, 1996, p. 146). Proactive companies are more prone to triggering actions in the face of demands that appear, and exploiting opportunities that suit their capabilities, introducing new products, services, techniques, and technologies (Covin \& Slevin, 1989; Tayanuova, 2011). Proactiveness is viewed as willingness to become involved in bold actions, and take preventive action to anticipate future needs. If they can do so in accordance with their capabilities, proactive companies tend to explore opportunities abroad. This propensity helps these companies to internationalize (De Clercq, Sapienza, \& Crijns, 2005).

Risk taking is described as "managers' preferences for bold versus cautious acts to achieve firm objectives, the extent to which they followed tried-and-true paths or tended to support projects in which the expected returns were certain" (Lumpkin \& Dess, 1996, p. 146). It is characterized by willingness to execute strategies that involve significant chances of costly failures and a bold posture by taking initiatives with uncertain results (Covin \& Slevin, 1989; Tayanuova, 2011). To analyze the empirical data, an effort was made to describe the categories in a language that makes them as verifiable as possible. The description of the analysis categories is summarized in Chart 1 . 
Chart 1

Description of Analytical Categories

\begin{tabular}{|c|c|c|}
\hline Analytical Categories & Description of Categories & Sources \\
\hline Proactiveness & $\begin{array}{l}\text { Anticipate and act on future needs whether or not related } \\
\text { to your current line of operations. } \\
\text { Take initiatives to compete aggressively with other firms. } \\
\text { Discard mature or declining lifecycle operations. } \\
\text { The opposite of reactivity. } \\
\text { First to propose innovations. } \\
\text { Shape the Environment. }\end{array}$ & $\begin{array}{l}\text { Lumpkin \& Dess (1996) } \\
\text { Tayanuova (2011, p. 572) }\end{array}$ \\
\hline Innovativeness & $\begin{array}{l}\text { Try new ideas } \\
\text { Stay away from established practices } \\
\text { Generate new products, processes, systems and approaches } \\
\text { Emphasis on R\&D, technological leadership and } \\
\text { innovations } \\
\text { The opposite of conservatism } \\
\text { New product and service lines or frequent, radical changes }\end{array}$ & $\begin{array}{l}\text { Tayanuova (2011, p. 572) } \\
\text { Covin \& Lumpkin (2011) } \\
\text { Miller \& Friesen (1982) }\end{array}$ \\
\hline Risk Taking & $\begin{array}{l}\text { Commit large resources to ventures that have a substantial } \\
\text { chance of costly failure. } \\
\text { Take strategic actions in the face of uncertainties } \\
\text { Willingness to undertake high risk but far-reaching projects } \\
\text { to maximize potential opportunities } \\
\text { Long-range actions with bold, aggressive stance } \\
\text { Performance in international funding }\end{array}$ & $\begin{array}{l}\text { Tayanuova (2011, p. 572) } \\
\text { Covin \& Slevin (1989) }\end{array}$ \\
\hline $\begin{array}{l}\text { International } \\
\text { Fundraising } \\
\text { Performance }\end{array}$ & Percentage of CSO budget from international funding & The authors \\
\hline
\end{tabular}

Source: prepared by the Authors (2018).

\section{METHODOLOGY}

This section is in keeping with the propositions of Eisenhardt (1989) and Bansal, Smith and Vaara (2018), that the method section should be as complete as possible. The steps taken to analyze the data were guided by Eisenhardt (1989), Saldaña, (2013) and Miles et al. (2014).

\subsection{Research ConteXt}

The data was collected from 2015 to 2016 . However, the questions referred to the previous fifteen years, since fundraising, use of funds, and international financial accountability spanned a number of years. The period of the study was characterized by the fact that, during this time, CSOs were put under growing pressure from IDAs to adopt managerial practices (Hvenmark, 2016; Mitchell, 2018) and professionalize their management. Donors increasingly requested results that could be demonstrated using quantifiable indicators and quick and verifiable impacts (Lewis, 2014; Missoni \& Alesani, 2014).

We analyzed Brazilian CSOs with various missions. They had all made efforts to raise international funds, and none of them was linked to any for-profit organizations; nor were they branch offices of CSOs with headquarters in other countries. These criteria were established to avoid the introduction of exogenous factors. IDAs are global institutions, such as the InterAmerican Development Bank (IDB) and the World Bank, with head offices in the United States or European Union. Some of the data pertaining to the CSOs involved in the study are shown in Chart 2. 
BBR

17

176

Chart 2

Data from the Six CSOs

\begin{tabular}{|c|c|c|c|c|c|c|}
\hline & OSC1 & OSC2 & OSC3 & OSC4 & OSC 5 & OSC6 \\
\hline Foundation & 1961 & 1991 & 1999 & 1946 & 2000 & 2007 \\
\hline $\begin{array}{l}\text { Mission/ } \\
\text { Scope }\end{array}$ & $\begin{array}{l}\text { Promote the } \\
\text { diagnosis, } \\
\text { prevention } \\
\text { and } \\
\text { inclusion of } \\
\text { people with } \\
\text { intellectual } \\
\text { disabilities. }\end{array}$ & $\begin{array}{l}\text { Guarantee to } \\
\text { children and } \\
\text { adolescents } \\
\text { with cancer } \\
\text { the right } \\
\text { to achieve } \\
\text { chances of } \\
\text { healing with } \\
\text { quality of } \\
\text { life. }\end{array}$ & $\begin{array}{l}\text { Offer small } \\
\text { businesses } \\
\text { belonging } \\
\text { to members } \\
\text { of excluded } \\
\text { minorities the } \\
\text { possibility to } \\
\text { sell products } \\
\text { and services } \\
\text { to large } \\
\text { corporations. }\end{array}$ & $\begin{array}{l}\text { Facilitate } \\
\text { through } \\
\text { education, } \\
\text { rehabilitation } \\
\text { and } \\
\text { promotion of } \\
\text { employability } \\
\text { the social } \\
\text { inclusion } \\
\text { of visually } \\
\text { impaired } \\
\text { people. }\end{array}$ & $\begin{array}{l}\text { Mitigate the } \\
\text { effects of climate } \\
\text { change through } \\
\text { scientific } \\
\text { research, } \\
\text { environmental } \\
\text { conservation, } \\
\text { and } \\
\text { community- } \\
\text { based } \\
\text { sustainability } \\
\text { activities. }\end{array}$ & $\begin{array}{l}\text { Promoting sustainable } \\
\text { development and } \\
\text { inclusive representation } \\
\text { of the rights and } \\
\text { interests of traditionally } \\
\text { excluded groups, } \\
\text { especially quilombola } \\
\text { communities. } \\
\text { Quilombola are } \\
\text { Brazilians who have } \\
\underline{\text { African ancestry. }}\end{array}$ \\
\hline Location & $\begin{array}{l}\text { SP State } \\
\text { Capital }\end{array}$ & $\begin{array}{l}\text { SP State } \\
\text { Capital }\end{array}$ & $\begin{array}{l}\text { SP State } \\
\text { Capital }\end{array}$ & $\begin{array}{l}\text { SP State } \\
\text { Capital }\end{array}$ & $\begin{array}{l}\text { Interior of } \\
\text { Tocantins State }\end{array}$ & Interior of SP State \\
\hline $\begin{array}{l}\text { Number of } \\
\text { employees } \\
\text { (Excluding } \\
\text { members of } \\
\text { the Board of } \\
\text { Directors) }{ }^{*}\end{array}$ & $\begin{array}{l}460 \\
\text { employees }\end{array}$ & $\begin{array}{l}658 \\
\text { employees }\end{array}$ & 2 employees & 184 employees & 2 employees & 2 employees \\
\hline
\end{tabular}

Source: Authors (2018) based on interviews, websites and annual reports.

* For CSOs 3, 5 and 6 the numbers of staff listed in the table are those who had been hired prior to fundraising. For all of them, the number of employees increased after that.

\subsection{Definition of Constructs and Analysis Criteria}

To analyze the $\mathrm{EO}$ of the CSOs, we used the definitions of proactiveness, innovativeness, and risk taking, that have been established in the literature, as presented above. To analyze whether an organization raised funds, and its relative performance, we sought to evaluate the absolute value of the funds raised during the period in question and to what extent this fundraising represented the budget of each organization. These values were requested through the questions that the interviewees were directly asked.

\subsection{Data Collection}

To identify the presence of EO within the six organizations in question, we sought evidence of behaviors that characterized proactiveness, innovativeness, and risk taking. Regarding the planning for the interviews, the questions that were drafted sought to elucidate these behaviors. The questions were prepared following the recommendations of Yin (2014) to distinguish the questions put to the researcher and to the interviewees. The interviewees were asked about the origin of the CSOs, their operations, changes to their structure and mission, introduction of new products and initiatives for international fundraising. The main questions that the researchers attempted to answer were to what extent the CSOs were entrepreneurially oriented, the CSOs' performance with regard to international fundraising, and the relationship between both these factors.

In addition to the 15 interviews with members who were working at the CSOs, five further interviews were conducted with people who were involved in the fundraising process or who knew the CSOs well: Two interviews were held with a former executive of two of the CSOs in 
the sample, and three were held with the Brazilian manager of a renowned IDA. Therefore, a total of 20 interviews were conducted.

Following the interviews, questionnaires were forwarded to each of the CSOs to confirm the information obtained during the interviews. The data collection included document research, and also queries to the web pages, which contained information on aspects such as project portfolios, reports and accountability to donors.

All the interviews were conducted in the presence of two researchers, recorded, and transcribed. Information on the interviewees is shown in Chart 3.

Chart 3

Interviews Conducted

\begin{tabular}{|c|c|c|c|c|c|c|}
\hline & CSO1 & $\mathrm{CSO} 2$ & CSO3 & CSO4 & CSO5 & CSO6 \\
\hline $\begin{array}{l}\text { Number of } \\
\text { interviewees }\end{array}$ & 3 & 2 & 5 & 5 & 2 & 3 \\
\hline $\begin{array}{l}\text { Interviewee } \\
\text { Position }\end{array}$ & $\begin{array}{l}\text { Superintendent } \\
\text { Fundraiser and } \\
\text { Institutional } \\
\text { Development } \\
\text { Research } \\
\text { Assistant }\end{array}$ & $\begin{array}{l}\text { General } \\
\text { Manager of } \\
\text { Institutional } \\
\text { Development } \\
\text { Fundraising } \\
\text { and } \\
\text { Institutional } \\
\text { Development } \\
\text { Coordinator }\end{array}$ & $\begin{array}{l}\text { - Vice President } \\
\text { - Technical } \\
\text { Manager and } \\
\text { Institutional } \\
\text { Relations } \\
\text { - Financial } \\
\text { Administrative } \\
\text { Manager. } \\
+ \\
\text { - Former OSC } \\
\text { Manager } \\
\text { - IDA Manager }\end{array}$ & $\begin{array}{l}\text { - Superintendent } \\
\text { - Inclusion Support } \\
\text { Services Manager } \\
\text { - Image and } \\
\text { Fundraising } \\
\text { Manager } \\
\text { - Free Revenue } \\
\text { Fundraising } \\
\text { Coordinator } \\
\text { - Project } \\
\text { Fundraising } \\
\text { Coordinator }\end{array}$ & $\begin{array}{l}\text { - President. } \\
+ \\
\text { - IDA } \\
\text { Manager }\end{array}$ & $\begin{array}{l}\text { - Project } \\
\text { Fundraising } \\
\text { Coordinator } \\
+ \\
\text { - Former } \\
\text { OSC } \\
\text { Manager } \\
\text { - IDA } \\
\text { Manager }\end{array}$ \\
\hline
\end{tabular}

Source: Authors (2018).

\subsection{Data Analysis}

The initial phase of the analysis consisted of gathering information on each CSO and seeking, in the collected material, signs of risk taking, proactiveness, and innovativeness and performance in international fundraising. The definitions of the categories used in the analysis are shown in Chart 1. These four categories were treated as codes. However, to remain consistent, in accordance with Stake (1995), who warned that the formal aggregation of categorical data can distract the researcher, most of our time was spent on direct interpretation. The results of the analysis of two cases were discussed with, and validated by, the interviewees.

To validate the amount of funds raised internationally by a CSO, the following criteria was used: in no year of the period in question did international fundraising surpass $1 \%$ of the CSO's budget (low fundraising); in some year of the period in question, the international fundraising accounted for $1 \%$ to $10 \%$ of the CSO's budget (medium fundraising); in at least one year of the period in question, international fundraising accounted for over $10 \%$ of the CSO's budget (high fundraising). The percentages were calculated using information on the amount of funds raised internationally provided by the interviewees. In the case of CSO2, the amount donated was informed through the balance published on the organization's website. 


\section{RESULTS}

\subsection{InTRA-CASE ANALYSIS}

\section{CSO1}

\section{Low international fundraising and low level of EO}

CSO1 was founded in the nineteen sixties with a mission of prevention, treatment of intellectual disabilities, and the social inclusion of people affected by them, a mission that has remained virtually unchanged until today. It promotes spreading knowledge regarding preventing and treating this condition, and striving for the inclusion of those who suffer from it. It introduced, in Brazil, procedures for prevention of intellectual disability, with a large laboratory that specializes in this field. It also promotes and guarantees the rights of people with intellectual disabilities. The organization's website has information that highlights its size and the quality of the services it provides.

In the interviews, the managers emphasized one aspect, which was the level of structuring of the administration, the accreditation it has achieved, and the fact that the organization was in the black. The organization has a strategic plan, indicators that are monitored on a quarterly basis, and a dashboard. It was highlighted that the professionalization process of the CSO has been under way for some time.

Regarding product innovation, improvements in the provision of services were mentioned, but the only change in the organization's operations was referred to by the interviewees as the introduction of "advocacy". The organization's revenue continues to stem from the provision of the services it has provided for decades, despite the fact that the continuity of these services is at risk of being affected by institutional and technological changes, which is a cause for management concern.

Concerning international fundraising, the interviewees frankly admitted that it was in its early stages. According to the professional in charge of developing this fundraising:

I've come to the conclusion that as this international fundraising is right at the beginning, embryonic, instead of investing, let's see how it works here first. The perspective is still that it will not bring in large amounts. So, we'll leave that investment for later.

The person that made the above statement was then the only person at the operational level that was dedicated to this task, and even so, only part time.

We considered the EO of CSO1 to be low despite the innovations introduced into the services it provides because the CSO's service portfolio has not changed significantly. The CSO requests donations using traditional methods, such as telemarketing, bazaars, and jumble sales. Organizations with high EO tend to be innovative, generating new products and processes, and shifting away from established practices. The way in which investment in IF is being done, with great caution so as not to compromise resources, suggests low risk taking. The only person that works in the field divides his time between this activity and another. Even small investments are carefully weighed and considered. The combination of both these factors indicates a low level of EO.' 


\section{$\mathrm{CSO} 2$}

Medium international fundraising and medium EO

CSO2 is dedicated to treating children and teenagers with cancer. Founded in the early 1990s,

the institution was a pioneer in the introduction of diverse treatments. The institution has a hospital with more than four thousand appointments in 2018, with $80 \%$ of these appointments being for low-income patients. Since 2017, it has been accredited by the Joint Commission International, an American non-profit association that assesses hospitals to determine the quality and safety of treatment for patients.

In terms of International Fundraising (IF), CSO2 has made efforts to raise funds this way for some time, with two people dedicated to this activity. Due to the disappointing results, they ceased to pursue this form of fundraising. Even so, CSO2 on several occasions raised millions of dollars in donations, the highest being 2.5 million dollars donated by an international foundation. Although impressive in absolute terms, these donations represented a small percentage (under $5 \%$ ) of the CSO's budget, which only in 2018 raised over one 30 million dollars in domestic contributions.

In accordance with the criterion that we defined in the methodology, we also judged the IF of CSO 2 as medium. The interviewees referred to few deviations from standard practices or new products during the period in question. The major innovations, such as the opening of the hospital, occurred in the nineties (due to the favorable context that arose following the passing of legislation for the Statute of Children and Teenagers) and its expansion in 2013. The fundraising practices, and institutional supporters, also date back to those days. We assessed CSO2 as medium in innovativeness, because it has updated its hospital and acted as a pioneer of several forms of treatment.

\section{CSO3}

\section{High international fundraising and high EO}

CSO3 was founded in 1999 with a mission to mitigate social exclusion, helping micro and small businesses belonging to members of minority communities, especially those of African descent, to enjoy greater access to business opportunities and income. The organization raised almost one million dollars from an IDA in its early days, when its team comprised only two employees and a voluntary board of directors. These funds allowed the CSO to change the scale of its operations and restructure itself administratively. One of the demands of the IDA prior to releasing the funds was for the CSO to raise substantial sums on its own at the national level.

My God! We grew so much [...]. Then, we had forty something companies donating. I can't remember the exact numbers, but we made a few million dollars in business, funding businesses on a scale we had never seen, with suppliers and buyers. And at the time, we got a line from [...] and $[. .$.$] , who also made our structure grow and enabled us to give more support.$

The representative of the IDA that granted the funds and the members of the CSO that were interviewed stated that the reason for the donation of the funds was fundamentally due to the innovative and inclusive nature of the mission and how it was made operational. "The project was very good and in alignment with the directives of the IDA" (IDA executive).

Another aspect that contributed to the granting of the funds was the proactive way in which the then principal executive of the CSO approached the IDA and attracted their attention to the organization's work, by attending conferences of an American institution with a similar 
mission. Through this approach, the representative of the international agency came to know the organization in Brazil and negotiations for investing funds in the CSO became feasible. Another helpful factor was that the executive president had promoted an event on social inclusion in Brazil at the IDA's American branch. The event promoted CSO3 at a number of levels at the IDA's head office. The negotiations of the CSO3 with the IDA was almost totally conducted at the head office and not, as is usual, at the local branch of the IDA. This strategy was described in detail by the executive that sponsored it, and it was confirmed by the manager of the local branch of the CSO3.

The CSO's risk taking was evidenced by the fact that it assumed commitments with the IDA to achieve bold operational results, which subjected the CSO to high levels of stress. These risks involved the national fundraising required by the IDA. Its innovativeness was characterized by the originality of the CSO's mission, which was a pioneering way of focusing on the social inclusion of minorities in Brazil.

An analysis of the interviews clearly shows that the innovative nature of the CSO's operations, focused on generating sustainable income for minorities, was what attracted the interest of the IDA, and led it to overlook the lack of structure and control when granting funds: "How hard it is to work individually with every micro and small business, so our strategy is to work through innovative organizations that have a mission to support our target audience."

\section{CSO4}

\section{Low international fundraising and low EO}

CSO4 was founded over six decades ago by a person with visual impairment. Despite her disability, she managed to go to school, become a teacher, and do a specialization course at an American university. When she returned, she began what would go on to become the largest national foundation for the social inclusion of people with visual disabilities. CSO4 operates in the areas of special education, rehabilitation, and the promotion of employability for persons with visual disabilities. It produces and distributes a high quantity of books and other reading material in Braille.

When the founder of CSO4 passed away, the organization underwent a restructuring and professionalization process, including in the area of fundraising, which had been dependent on the founder. As she was a well-known and recognized figure, she succeeded in attracting major contributions. This professionalization, however, could not prevent the organization from undergoing a financial crisis. This was caused by a fall in fundraising and the loss of a government contract that, through the purchase of books in Braille, generated approximately $30 \%$ to $50 \%$ of the CSO's revenues.

At that time, we basically lived by the Rouanet Law, so we printed books, distributed books, produced books, leaflets or other projects, presented them to the Ministry of Culture, and they would say 'All right, you can raise funds through this law that gives you the incentive'. And then we put it out there.

Regarding international fundraising, one interviewee referred to several growing difficulties:

[...] because they're not here, but their money is. We see that companies are getting more demanding, they want to know where the money is being spent, more and more they ask this. We had a bank account. Everything went to that account. Not anymore. We have to have a separate account. We have to send them the statement for each project's account. 
International calls for applications and proposals have very specific themes. So, the issue is water, poverty, female empowerment, local communities, basic economics. These are highly specific issues that they see in underdeveloped countries and it doesn't fit in our case.

With international calls for proposals, the work is a little more complicated because there are so many items involved. So, the common formula in Brazil is like this: goal, target audience, justification, schedule and intended result, and that's it. For them, you have to put this together with that, goal by goal, with the results proposed by the European Union. Then you have to understand what the European Union wants, what is required for the project, what you have, and then you have to link all of these things together to prepare an argument.

With regard to international fundraising, efforts in this respect are in their early stages and depend on the initiative of one person. The largest investment made by the CSO in this respect so far was to sponsor an employee's trip to England for a short time.

The CSO is classified as having low proactiveness because it has not succeeded in taking preventive measures regarding the risks of losing funding from two important sources that it has had for many years. Because it has depended for so long on one service as the source of $50 \%$ of its budget, its innovativeness was classified as low.

\section{CSO5}

\section{High international fundraising and high EO}

CSO5 was founded in 2000 in the north of Brazil. Its mission was to reduce the effects of climate change through scientific research, environmental conservation projects, and the preservation and development of communities. It is the owner of a brand and patented social technology for carbon reduction, which combines the effects of environmental improvement with the socioeconomic development of vulnerable communities, and has been used in a number of countries, including Switzerland, India, Turkey, China, and South Africa.

CSO5 was a pioneer in Brazil in implementing carbon sequestration as a way of mitigating climate change. Its environmental preservation method is unique in its concern over guaranteeing the rights of affected populations, often indigenous tribes. CSO5 opened a research center for renewable energy, studying the possibility of generating fuel from native species of vegetation from the Cerrado region. It implemented nurseries with a potential for hundreds of thousands of native saplings per year:

\footnotetext{
We opened five large nurseries with a potential for a hundred thousand saplings a year each, and we then demarcated indigenous areas with funds from Germany.

We developed projects. In addition to climate change, we went in other directions, renewable energy, sustainable business, and we also raised funds to implement craft centers and product processing centers.

Nobody knew how to deal with these large hydroelectric ventures. So, we created a whole methodology and then it was translated into five indigenous languages.
}

CSO5 was sponsored for four years by a global company in the electric power sector. Significant international funds were received from 1998 to mid-2004. "This craft center was funded from Italy. It also had some funding from Japan. [...] The grant from USAID funded this program, which was called Tocantins Energy, Education and Participation.”

As around 50\% of CSO's expenses were covered by resources from international funding for several years, we evaluated its IF as high. The innovativeness of its mission and the proactiveness in its implementation led us to consider its $\mathrm{EO}$ as high. 
BBR

17

182

\section{CSO6}

\section{High international fundraising and high EO}

CSO6 is located in one of the least developed regions of the country. Its mission is to promote the inclusion of historically excluded groups, such as quilombo communities. The community assisted by the organization is made up of farmers who practice subsistence agriculture.

With its first project, CSO6 enabled part of the population of the region to attend higher education institutions through distance learning. This initiative led to the organization receiving funds from an IDA for its second project. However, the funding for the second project was suspended because the institution could not comply with certain contractual clauses.

The behavior of CSO6 shows signs of proactiveness, innovativeness, and risk propensity, and its EO is therefore considered high. The fact that a small CSO, with almost no formal structure, accessed an IDA and raised funds, in addition to affecting the education level of the entire population that it serves, is evidence of proactiveness. As it assumed high level commitments, including raising matching funds, and achieving bold goals, it showed signs of risk taking. Therefore, we classified its EO as high. The funds raised show that its level of international fundraising should also be considered high.

\subsection{Inter-Case Analysis}

When, following the script proposed by Eisenhardt (1989), we came to conduct the inter-case analysis, we observed similarities between the three CSOs that raised significant international funds (relative to their budgets) and those that did not, as well as differences between the two groups. One of the similarities was that the organizations that raised funds showed more evidence of entrepreneurial behaviors, both in their approach and in the way that they raised funds.

A result that emerged from the data was that the larger and older organizations raised few funds, while the smaller ones enjoyed high levels of fundraising. A surprising result was that the more professionalized organizations raised fewer funds, while those with little professionalization raised more. These results led us to return to the data and the literature in an attempt to understand the how and why of these results.

The relationship between EO and IF is clearly demonstrated in Chart 4. The contrasting figure is a useful device when the analyst is attempting to understand how a result "plays itself out across different cases" (Miles, Huberman \& Saldana, 2014, p. 150). Nevertheless, as our sample is not random, the relationship is a result of little significance. It is interesting to establish how and, if possible, why the constructs are related.

Chart 4

Contrast Between Categories - EO and International Fundraising

\begin{tabular}{|c|c|c|c|c|c|c|}
\hline \multirow{2}{*}{$\begin{array}{l}\text { Categories } \\
\text { CSOs }\end{array}$} & \multicolumn{3}{|c|}{ CSOs with High International Fundraising } & \multicolumn{3}{|c|}{$\begin{array}{l}\text { CSOs with Low or Medium } \\
\text { International Fundraising }\end{array}$} \\
\hline & $\mathrm{CSO} 3$ & $\mathrm{CSO} 5$ & CSO6 & CSO 1 & $\mathrm{CSO} 2$ & CSO4 \\
\hline $\begin{array}{l}\text { International } \\
\text { Fundraising }\end{array}$ & High & High & High & Low & Average & Low \\
\hline $\mathrm{EO}$ & High & High & v High & Low & Average & Low \\
\hline
\end{tabular}

Source: Authors (2018). 


\subsubsection{Risk taking and IF}

When we looked at CSOs 1, 2 and 4, which raised low and medium levels of international funds, what attracted our attention was the extremely measured and gradual form of committing their few resources to the task of fundraising. Furthermore, it was only recently, decades after they were founded, that these organizations made their first efforts to this end. CSO1 and CSO4 are dedicating only part of a professional's time to fundraising. Even so, when these people were interviewed, doubts were raised over whether this task was more of a personal rather than an institutional undertaking. CSO2 had made efforts to raise funds, but as these efforts did not bear fruit, they were suspended.

The behavior of CSOs 1, 2, and 4 contrasts with that of the other CSOs that succeeded in raising funds, especially CSO3. This organization, even with few resources, funded executives' trips overseas and paid to bring and provide accommodation for an executive from an IDA to Brazil. When it comes to risk taking, it is interesting that the three fundraising CSOs $-3,5$ and 6 - that raised international funds from a renowned IDA, agreed to commit to bold operational goals and to raise large sums with national agencies, in reciprocity to the funds received form the IDAs.

The reasons why risk taking and fundraising are correlated can also be deduced from the collected data. IDAs increasingly demand quantifiable and impactful results that can be verified through auditing (Lewis, 2014; Missoni \& Alesani, 2014). Raising high levels of funds means committing to goals and targets that are difficult to achieve. The stress that CSO3 faced to meet its goals and the fact that CSO6 did not achieve its goals and had its funding suspended are evidence of these risks. Fundraising involves the commitment of work and resources, without any guarantees that the funds will be received. Therefore, it involves risks, an analysis of which led us to formulate the first proposition.

Proposition 1. Low risk-taking leads CSOs to postpone their IF initiatives and, when they take risks, to commit few resources. The combination of postponing and investing few resources lead to low IF.

\subsubsection{Innovativeness and IF}

Whereas the CSOs with low or medium IF have missions of assistance, the missions of the others are concerned with sustainability or diversity, issues that have gained visibility in recent years. The difficulty involved in fundraising for CSOs with assistance tendencies through calls for applications and proposals was angrily referred to by interviewees from the three CSOs with low levels of IF. According to them, social organizations with assistance missions have "been blown off the map". The priorities of the international agencies are "fads", cycles of interest in one subject or theme or another. International funding agencies have sought to finance CSOs that promote the autonomy of the people they assist and whose efforts are increased by a multiplying effect.

In the words of one interviewee who succeeding in raising international funds, "You have to study the site really well to know what they want in terms of this year's policies."

Meanwhile, according to the representative of the IDA, "They (the CSOs) are right when they say that Brazil went off the radar, and it's true, from an assistance viewpoint, that Brazil is at the back of the queue."

On the other hand, the interviewee also referred to the missions that IDAs are valuing, which we would call contemporary: 
BBR

17

184
Although I would not say that it's all about SDGs (sustainable development goals), we are talking about sustainability, green growth, gender. These are the themes of the world that we want to work with, integrated and sustainable development [...] [...] That's what they want now. It's what everyone wants: sustainable, integrated and inclusive development.

The fact that the missions of the CSOs that raise funds are in alignment with the "premises" of IDAs cannot be dissociated from the fact that they emerged recently. However, it cannot be reduced to this. The way that $\mathrm{CSO} 3$ aids the social inclusion of excluded minorities, for instance, has always been innovative.

Proposition 2. Innovative CSOs tend to adopt contemporary missions in keeping with the agendas of IDAs, which favor IF.

\subsubsection{Proactiveness and IF}

An interesting fact with regard to proactiveness is that the CSOs that raised the most international funds, practically since the day they were founded, have considered international funding as an opportunity for obtaining resources. Willingness to make bold moves in order to exploit opportunities is a characteristic of proactive organizations. One of the characteristics of proactive companies is that they tend to seek more opportunities overseas (De Clercq et al., 2005). CSO3, with daring and determination, sought to access international funding almost from its founding, and succeeded in this goal by directly contacting the head office of the IDA, bypassing the steps usually followed by an organization that seeks these funds. CSO5 has also been involved in international calls for applications and proposals almost since the day it was founded.

The proactiveness of the organizations that raises funds can also be seen in the extension and impact of their achievements. CSO3 succeeded in making the micro and small businesses it supports achieve sales to the order of twenty million dollars. These data are audited by the IDA. $\mathrm{CSO} 5$ succeeded in reducing carbon emissions by over four hundred thousand tons and its methodology has been used in around sixty projects in four countries. CSO6 managed to take higher education to a socially isolated minority community.

Proposition 3. Proactive CSOs boldly exploit opportunities for funding, which favors IF. The relationships expressed in the propositions are shown in graphic form in Figure 1.

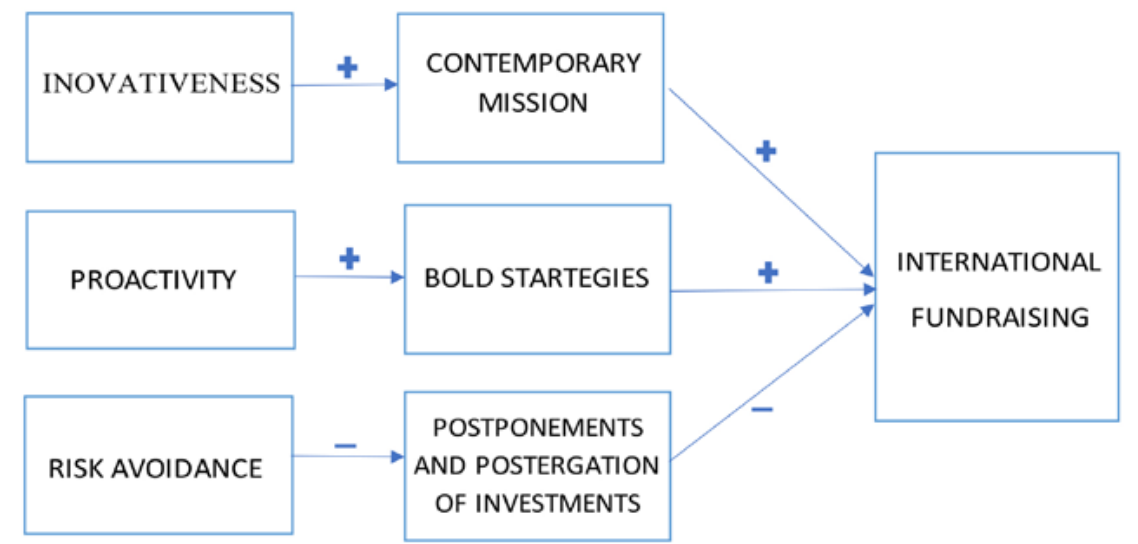

Figure 1. Relationship between EO and IF.

Source: Authors (2018). 
This study offers several insights into the relationship between EO and IF by CSOs. A key insight is that CSOs with EO are more successful in the IF process. This result is important because, as noted by Morris et al. (2011), non-profit organizations represent quite a different context than the one in which the relationship between EO and performance has been verified repeatedly. CSO's are formed to fulfill a social need, not the needs of shareholders, are self-governing, and do not distribute dividends.

The research results reinforce and broaden those of Rank and Strenge (2018), for example. These authors suggest EO is important for the performance of organizations in various fields, but they do not include nonprofit organizations among them. Wales et al. (2011), in a comprehensive review of the empirical literature, analyzed 158 articles about EO. The authors identified 55 dependent variables that were explored in these articles. International Fundraising (IF) is not one of them. In the same vein, our results also broaden the knowledge about the relationship between EO and international performance. The research by Covin and Miller (2014), Liu, Li and Xue (2011), Weerawardena et al. (2007), and Knight and Liesch (2016) points out that organizations which have high EO, tend to perform better in international expansion. The authors, however, did not consider the IF of CSOs as a possible aspect of internationalization. This research contributes to the expansion of the theoretical field of application of the concept of $\mathrm{EO}$ as it helps in the incremental refinement of its scope of its application.

More specifically, we analyzed the relationship of each of the three sub-dimensions of EO and IF and made propositions about how this relationship takes place. The analysis of this relationship is a theoretical contribution because research is just beginning to elucidate the causal processes through which EO is able to influence specific outcomes (Wales et al., 2011).

With regard to risk tolerance, we found that CSOs that succeeded at IF made commitments to operational goals that were difficult to achieve, starting at early stages of their life cycles. In contrast, in those that did not succeed, we identified behaviors denoting risk aversion. Regarding IF, they delayed investments in the search for funding and, when they did it, it was with low commitment of resources. This result is important because previous studies (Wiseman \& Catanach, 1997; Lyon, Lumpkin, \& Dess, 2000; Naldi, Nordqvist, Sjöberg, \& Wiklund, 2007) have shown mixed results on the relationship between risk tolerance and performance. The authors state that one reason the results are inconclusive is that the governance structure, as well as the context of organizations, influences managers' risk behavior.

In terms of proactivity, we found that CSOs that succeeded in IF developed bold actions and explored opportunities more than those that were unsuccessful. This boldness and exploitation of opportunities also manifested in the form of seeking IF. This result is interesting from a theoretical point of view, because this $\mathrm{OE}$ sub-dimension is associated in the literature with the introduction of new services ahead of competitors (Covin \& Slevin, 1989; Lumpkin \& Dess, 2001). However, in the non-profit environment, organizations typically do not compete for market-share, which would have made us expect that proactivity would not have been relevant for outcomes in this context, the opposite of what has happened.

The result we found with regard to innovativeness, that innovative CSOs tend to adopt contemporary missions aligned with IDA's agenda, which in turn favor IF, is in line with existing research. Kreiser, Marino, Kuratko and Weaver (2013, p. 276), for example, in the literature review that justify the hypotheses they test in the article, stating: "Innovative firms continuously 
BBR

17

186

introduce new products and services that are more attuned to current and emerging market needs". Our contribution is in that we found arguments suggesting this alignment continues to exist in a different context from the one in which it was previously verified. We have also showed forms in which the alignment takes place in this different context. Showing, with examples, how a relation between constructs operates is a powerful contribution of case studies (Siggelkow, 2007).

This study also contributes to the theoretical expansion of the construct by analyzing the relevance of EO in Brazil, a country in which the lack of research on EO is "glaring" (Wales et al., 2011, p. 364). As the same authors point out, the virtual non-existence of studies in Latin America, Sub-Saharan Africa, and the Middle East, is remarkable, because these regions have very different socio-cultural contexts than those prevailing in the United States and other developed countries, where most studies were conducted. The fact that Latin America is a region with few EO studies is also pointed out by Martens, Lacerda, Belfort, and Freitas (2016) who, in a literature review, show that this region is one of the four poorest in the planet, in studies about the construct.

The importance of conducting research on EO with less generalized samples, particularly in the non-profit sector, has been voiced by a number of researchers (George \& Marino, 2011; Morris et al., 2011; Wales, 2016). Our study is in keeping with authors who advocate seeking to understand how EO boosts performance in particular contexts (Wales, 2013, 2015). Conducting this study in qualitative terms is in alignment with the need, repeated by several authors, for studies that follow this type of methodology and offer insights into how EO plays out in organizations.

The study results have several practical implications. For CSO managers, the most direct one is that if they intend to raise IF, they should be mindful of promoting EO in their organizations. The study indicates behaviors that derive directly from each of the three sub-dimensions of EO and how they affect IF. Another contribution to managers is that the study describes the behaviors successful CSOs adopted. Access to information on how they did it can inspire and facilitate discussion by other CSOs of the desirability of adopting practices that have been successful.

A further practical implication is for CSOs managers to consider that, for IDAs, contemporary missions arising from innovative behaviors, aligned with the agencies' current missions, can outweigh in attractiveness the risks involved in financing less structured CSOs. That is, the study suggests that IDAs may be willing to fund CSOs where risks of non-compliance are present, if the mission of the CSO is innovative and aligned with the IDAs areas of interest. This was verbalized by an IDA manager in an interview, and seems to have happened with the CSOs that succeeded in IF. This result is particularly interesting because of the fact that IDAs are willing to take a certain level of risk seems to have escaped CSO's managers. This disposition also did not appear in our literature review that, on the contrary, indicated consensus that IDAs are more and more increasing level of controls they demand from CSOs (Wallace, 2004; Ferrari, 2014; Missoni \& Alesani, 2014). The study also suggests that seeking ways to access influential IDA managers and getting their attention can bring good results. 


\section{FINAL CONSIDERATIONS}

\subsection{LimitaTions OF THE STUDY}

The study analyzed a non-random sample of six CSOs. Due to the low number of CSOs, not only the relationship that we found but also how it occurs may be unique to this group of organizations and may not be verifiable in others. Despite the care we took to reduce the possibility of introducing bias, the analysis involved numerous instances of data interpretation and, as such, this may have introduced inaccuracies and even distortions into their reading. As with any comparative case study, our insights cannot be generalized. Case studies are adequate to offer realistic and accurate interpretations of a phenomenon that the researcher fits into a framework. With this, it provides means for the extension and advancement of theory (Harrison \& Corley, 2011; Villani, Greco, \& Phillips, 2017).

\subsection{Suggestions for Future Studies}

The study points out opportunities for further research to gain a better understanding of IF by CSOs and the role of EO in this phenomenon. A relationship that appeared in the sample of the six CSOs in question, but was not explored in this study, is between the size and age of the organizations and EO. These relationships are negative in the sample that we analyzed. These results are consistent with previous studies in other contexts, but it would be interesting to show how this relationship occurs in the context of this study. Likewise, the data suggests that there may be a negative relationship between IF and professionalism. The three CSOs that successfully raised funds at the international level were far less structured and professionalized when they raised the funds than those that were less successful. This result is interesting because it contradicts a virtual consensus among researchers in the field that professionalization is necessary for IF, and deserve to be further investigated.

\section{REFERENCES}

Aldashev, G., \& Verdier, T. (2010). Goodwill bazaar: NGO competition and giving to development. Journal of Development Economics, 91(1), 48-63. https://doi.org/10.1016/j.jdeveco.2008.11.010

Anheier, H. K. (2014). Nonprofit organizations: Theory, management, policy (2nd ed.). New York: Routledge.

Appe, S., \& Pallas, C. L. (2018). Aid reduction and local civil society: Causes, comparisons, and consequences. Voluntas, 29(2), 245-255. https://doi.org/10.1007/s11266-017-9846-0

Austin, J., Stevenson, H., \& Wei-Skillern, J. (2006). Social and commercial entrepreneurship: Same, different, or both? Entrepreneurship: Theory and Practice. https://doi.org/10.1111/j.15406520.2006.00107.x

Bansal, P. T., Smith, W. K., \& Vaara, E. (2018). New ways of seeing through qualitative research. Academy of Management Journal, 61(4), 1189-1195. https://doi.org/10.5465/amj.2018.4004

Boris, E. T., \& Steurle, E. C. (2006). Scope and dimensions of the nonprofit sector. In W. W. Powell, \& R. Steinberg (Eds.), The nonprofit sector: A research handbook (2nd ed., p. 659). London: Yale.

Buijze, R. (2017, July). Strategies in international fundraising for the arts [working paper], 13-14. 
BBR

17

188

Covin, J. G., \& Lumpkin, G. T. (2011). Entrepreneurial orientation theory and research: Reflections on a needed construct. Entrepreneurship: Theory and Practice, 35(5), 855-872. https://doi.org/10.1111/j.1540-6520.2011.00482.x

Covin, J. G., \& Miller, D. (2014). International Entrepreneurial Orientation: Conceptual Considerations, Research Themes, Measurement Issues, and Future Research Directions. Entrepreneurship Theory and Practice, 38(1), 11-44. https://doi.org/10.1111/etap.12027

Covin, J. G., \& Slevin, D. P. (1989). Strategic Management of Small Firms in Hostile and Benign Environments. Strategic Management Journal, 10(1), 75-87. https://doi.org/10.1002/ smj.4250100107

Covin, J. G., \& Wales, W. J. (2018). Crafting High-Impact Entrepreneurial Orientation Research: Some Suggested Guidelines. Entrepreneurship Theory and Practice. https://doi. org/10.1177/1042258718773181

Cui, L., Fan, D., Guo, F., \& Fan, Y. (2018). Explicating the relationship of entrepreneurial orientation and firm performance: Underlying mechanisms in the context of an emerging market. Industrial Marketing Management, 71(August 2015), 27-40. https://doi.org/10.1016/j. indmarman.2017.11.003

Dai, L., Maksimov, V., Gilbert, B. A., \& Fernhaber, S. A. (2014). Entrepreneurial orientation and international scope: The differential roles of innovativeness, proactiveness, and risk-taking. Journal of Business Venturing, 29(4), 511-524. https://doi.org/10.1016/j.jbusvent.2013.07.004

De Clercq, D., Sapienza, H. J., \& Crijns, H. (2005). The internationalization of small and medium-sized firms. Small Business Economics, 24, 409-419. https://doi.org/10.1007/s11187005-5333-x

Eisenhardt, K. M. (1989). Building Theories from Case Study Research Kathleen M. Eisenhardt. Academy of Management Review, 14(4), 532-550.

Fernández-Mesa, A., \& Alegre, J. (2015). Entrepreneurial orientation and export intensity: Examining the interplay of organizational learning and innovation. International Business Review, 24(1), 148-156. https://doi.org/10.1016/j.ibusrev.2014.07.004

Ferrari, M. (2014). Captação de recursos em organização da sociedade civil. Pensamento \& Sociedade, 29(2), 63-82.

Gallagher, N., \& Meyers, L. (2016). Tools for grassroots activists: Best practices for success in the environmental movement. Ventura, Canada: Patagonia.

Gamble, E. N., \& Moroz, P. W. (2014). Unpacking Not-for-profit Performance. Journal of Social Entrepreneurship, 5(1), 77-106. https://doi.org/10.1080/19420676.2013.834457

Gautier, A., \& Pache, A. C. (2013). Research on Corporate Philanthropy: A Review and Assessment. Journal of Business Ethics, 126(3), 343-369. https://doi.org/10.1007/s10551-013-1969-7

George, B. A., \& Marino, L. (2011). The epistemology of entrepreneurial orientation: Conceptual formation, modeling, and operationalization. Entrepreneurship: Theory and Practice, 35(5), 989-1024. https://doi.org/10.1111/j.1540-6520.2011.00455.x

Harrison, S. H., \& Corley, K. G. (2011). Clean climbing, carabiners, and cultural cultivation: Developing an open-systems perspective of culture. Organization Science, 22(2), 391-412. https://doi.org/10.1287/orsc.1100.0538

Herzer, D., \& Nunnenkamp, P. (2013). Private Donations, Government Grants, Commercial Activities, and Fundraising: Cointegration and Causality for NGOs in International Development Cooperation. World Development, 46, 234-251. https://doi.org/10.1016/j.worlddev.2013.02.010 
Hvenmark, J. (2016). Ideology, Practice, and Process? A Review of the Concept of Managerialism in Civil Society Studies. Voluntas, 27(6), 2833-2859. https://doi.org/10.1007/s11266-0159605-z

Knight, G. A., \& Liesch, P. W. (2016). Internationalization: From incremental to born global. Journal of World Business, 51(1), 93-102. https://doi.org/10.1016/j.jwb.2015.08.011

Kreiser, P. M., Marino, L. D., Kuratko, D. F., \& Weaver, K. M. (2013). Disaggregating entrepreneurial orientation: The non-linear impact of innovativeness, proactiveness and risk-taking on SME performance. Small Business Economics, 40(2), 273-291. https://doi. org/10.1007/s11187-012-9460-x

Langley, A., \& Abdallah, C. (2011). Templates and Turns in Qualtative Studies of Strategy and Management. Research Methodology in Strategy and Management, 6, 201-235. https://doi. org/10.1108/S1479-8387(2011)0000006007

Lewis, D. (2014). Non-governmental organizations, management and development (3rd ed.). Abingdon, Oxon: Routledge.

Liu, Y., Li, Y., \& Xue, J. (2011). Ownership, strategic orientation and internationalization in emerging markets. Journal of World Business, 46(3), 381-393. https://doi.org/10.1016/j. jwb.2010.07.012

Lumpkin, G. T., \& Dess, G. G. (1996). Clarifying the entrepreneurial orientation construct and Linking it to performance. Academy of Management Review, 21(1), 135-172.

Lumpkin, G. T., \& Dess, G. G. (2001). Linking two dimensions of entrepreneurial orientation to firm performance: The moderating role of environment and industry life cycle. Journal of Business Venturing, 16(5), 429-451. https://doi.org/10.1016/S0883-9026(00)00048-3

Lyon, D. W., Lumpkin, G. T., \& Dess, G. G. (2000). Enhancing entrepreneurial orientation research: Operationalizing and measuring a key strategic decision making process. Journal of Management, 26(5), 1055-1085. https://doi.org/10.1177/014920630002600503

Martens, C. D. P., Lacerda, F. M., Belfort, A. C., \& Freitas, H. M. R. de. (2016). Research on entrepreneurial orientation: current status and future agenda. International Journal of Entrepreneurial Behaviour and Research. https://doi.org/10.1108/IJEBR-08-2015-0183

Miles, M. B., Huberman, M. A., \& Saldana, J. (2014). Qualitative Data Analysis: A methods sourcebook (3rd ed.). Thousand Oaks, CA: Sage Publications.

Miller, D. (1983). The correlates of entrepreneurship in three types of firms. Management Science, 29(7), 770-791.

Miller, D. (2011). Miller (1983) revisited: A reflection on EO research and some suggestions for the future. Entrepreneurship: Theory and Practice, 35(5), 873-894. https://doi.org/10.1111/ j.1540-6520.2011.00457.x

Miller, D., \& Friesen, P. H. (1982). Innovation in conservative and entrepreneurial firms: Two models of strategic momentum. Strategic Management Journal, 3(1), 1-25. https://doi. org/10.1002/smj.4250030102

Missoni, E., \& Alesani, D. (2014). Management of International Institutions and NGOs: Frameworks, practices and challenges. New York: Routledge.

Mitchell, G. E. (2018). Modalities of Managerialism: The "Double Bind" of Normative and Instrumental Nonprofit Management Imperatives. Administration and Society, 50(7), 10371068. https://doi.org/10.1177/0095399716664832 
BBR

17

190

Morris, M. H., Webb, J. W., \& Franklin, R. J. (2011). Understanding the manifestation of entrepreneurial orientation in the nonprofit context. Entrepreneurship: Theory and Practice, 35(5), 947-971. https://doi.org/10.1111/j.1540-6520.2011.00453.x

Moss, Tod; Short, Jeremy; Payne, G; Lumpkin, G.T. (June 2011). Dual Identities in Social Ventures: An Exploratory Study. Entrepreneurship: Theory and Practice 35(4):805 - 830 . https://doi.org/10.1111/j.1540-6520.2010.00372.x

Naldi, L., Nordqvist, M., Sjöberg, K., \& Wiklund, J. (2007). Entrepreneurial orientation, risk taking, and performance in family firms. Family Business Review, 20(1), 33-47. https://doi. org/10.1111/j.1741-6248.2007.00082.x

Pereira, C. (2001). Captação de recursos fund raising: Conhecendo melhor porque as pessoas contribuem. São Paulo: Editora Mackenzie. 222 páginas.

Rank, O. N., \& Strenge, M. (2018). Entrepreneurial orientation as a driver of brokerage in external networks: Exploring the effects of risk taking, proactivity, and innovativeness. Strategic Entrepreneurship Journal, 12(4), 482-503. https://doi.org/10.1002/sej.1290

Rauch, A., Wiklund, J., Lumpkin, G. T., \& Frese, M. (2009). Entrepreneurial orientation and business performance: An assessment of past research and suggestions for the future. Entrepreneurship: Theory and Practice, 33(3), 761-787. https://doi.org/10.1111/j.15406520.2009.00308.x

Salamon, L. M., \& Anheier, H. K. (1997). Defining the nonprofit sector: A cross-national analysis. In Johns Hopkins nonprofit sector series 4.

Salamon, L. M., Sokolowski, S. W., Megan, A., \& Tice, H. S. (2013). The state of global civil society and volunteering: Latest findings from the implementation of the UN Nonprofit Handbook. Working Papers of the John Hopkins Comparative Nonprofit Sector Project.

Saldaña, J. (2013). The coding manual for qualitative researchers (2nd ed.). London: Sage Publications.

Siggelkow, N. (2007). Persuasion with case studies. Academy of Management Journal, 50(1), 2024. https://doi.org/10.5465/AMJ.2007.24160882

Slevin, D. P., \& Terjesen, S. A. (2011). Entrepreneurial orientation: Reviewing three papers and implications for further theoretical and methodological development. Entrepreneurship: Theory and Practice, 35(5), 973-987. https://doi.org/10.1111/j.1540-6520.2011.00483.x

Stake, R. E. (1995). The art of case study research. Thousand Oaks, CA: Sage.

Stankiewicz, J., \& Seiler, B. (2013). The methods of raising philanthropic funds in the management of non-governmental organization; determinants. Management, 17(2), 63-73.

Tayauova, G. (2011). The impact of international entrepreneurial orientation on strategic adaptation. Procedia - Social and Behavioral Sciences, 24, 571-578. https://doi.org/10.1016/j. sbspro.2011.09.078

Uncapher, P. C. (2013). The relationship between entrepreneurial orientation and organizational effectiveness: An analysis of how entrepreneurial orientation is manifested in the nonprofit context organizational effectiveness: An analysis of how entrepreneurial. St. John Fisher College Fisher Digital Publications (No. 160).

Villani, E., Greco, L., \& Phillips, N. (2017). Understanding value creation in public-private partnerships: A comparative case study. Journal of Management Studies, 54(6), 879-905. https:// doi.org/10.1111/joms. 12270 
Wales, W. J. (2016). Entrepreneurial orientation: A review and synthesis of promising research directions. International Small Business Journal, 34(341), 3-15. https://doi. org/10.1177/0266242615613840

Wales, W. J., Gupta, V. K., \& Mousa, F.-T. (2011). Empirical research on entrepreneurial orientation: An assessment and suggestions for future research. International Small Business Journal, 31(4), 357-383.

Wales, W., Monsen, E., \& McKelvie, A. (2011). The Organizational Pervasiveness of Entrepreneurial Orientation. Entrepreneurship Theory and Practice, 35(5), 895-923. doi:10.1111/j.15406520.2011.00451.x

Wales, W. J., Wiklund, J., \& McKelvie, A. (2013). What about new entry? Examining the theorized role of new entry in the entrepreneurial orientation-performance relationship. International Small Business Journal, 33(4), 351-373. https://doi.org/10.1177/0266242613506023

Wallace, T. (2004). NGO Dilemmas: Trojan Horses for Global Neoliberalism? Socialist Register, 40(40), 202-219. Retrieved from http://socialistregister.com/index.php/srv/article/ download $/ 5818$

Weerawardena, J., Mort, G. S., Liesch, P. W., \& Knight, G. (2007). Conceptualizing accelerated internationalization in the born global firm: A dynamic capabilities perspective. Journal of World Business, 42(3), 294-306. https://doi.org/10.1016/j.jwb.2007.04.004

Wiklund, J., \& Shepherd, D. A. (2011). Where to from here? EO-as-Experimentation, failure, and distribution of outcomes. Entrepreneurship Theory and Practice, 35(5), 925-946.

Wiseman, R. M., \& Catanach, A. H. (1997). A longitudinal disaggregation of operational risk under changing regulations: Evidence from the savings and loan industry. Academy of Management Journal. https://doi.org/10.2307/256949

Yin, R. K. (2014). Case study research: Design and methods (5th ed.). Thousand Oaks, CA: Sage Publications.

Zappala, G., \& Lyons, M. (2006). Factors associated with fundraising dependency among nonprofit organisations in Australia. Australian Journal of Social Issues, 41(4), 399417. Retrieved from http://search.proquest.com.molly.ruc.dk/docview/61716024/ C468B75BD9BB48A9PQ/11 ?accountid $=14732$

Zhang, X., Ma, X., \& Wang, Y. (2012). Entrepreneurial orientation, social capital, and the internationalization of SMEs: Evidence from China. Thunderbird International Business Review, 54(2), 195-210.

Zucchella, A., \& Magnani, G. (2016). International entrepreneurship: Theoretical foundations and practices (2nd ed.). New York: Palgrave Macmillan. 